\title{
The Contestation of Organic and Non-Organic Agricultural Knowledge in Sustainable Agriculture
}

\author{
Siti Wardah \\ Darmawan Salman \\ Andi Agustang \\ Imam Mujahidin Fahmid \\ Sociology Department, Universitas Negeri Makassar \\ Jln. Bonto Langkasa Kampus Gunung Sari Baru, Makassar, South Sulawesi, Indonesia \\ Email: wardahlmsiti@gmail.com, darsalman@hotmail.com, andiagust63@gmail.com,mujahidin@yahoo.com
}

Doi:10.5901/mjss.2017.v8n2p245

\section{Abstract}

This research aims to analyze the contestational process between organic and non-organic agricultural knowledge in the agricultural practices in Bonto Lebang, North Galesong, Takalar regency. This was a qualitative study exploring descriptive data in oral, written and attitudinal forms obtained from farmers and other parties concerned as an agent of sustainable agriculture in Bonto Lebang, Takalar regency. It was a case study focused on hermeneutics. The data used in conducting this research were primary and secondary data. The results of this research show that the contestation between organic and nonorganic agricultural knowledge of seeds-providing, fertilizing or land-managing was given responses from each local of subsystems such as household, government, local communities, and marketing. For the people in Bonto Lebang village Takalar regency in particular, knowledge of organic agriculture was in fact a deconstructed agricultural knowledge resulting from field experiences and some informations from the agricultural consultants that got improved from self-practices. Meanwhile, agricultural parts that mainly changed were the important parts namely maintenance using the vegetable pestiside and fertilization using the organic fertilizer. The novelty of this research is the ontology focused on knowledge or skills in organic agriculture as a social reality by assuming that behind any knowledge and skills there existed a power and authority to transform the knowledge into a social practice and then it gradually turned into social reality.

Keywords : agricultural, organic, non-organic, sustainable

\section{Introduction}

Organic agriculture is an organic plantation without fertilizer and synthetic chemical pesticide. Principally, it improves the condition of plant roots by regulating the irrigation, bearing only a single plant, early timing of plantation, and improving land quality, as the result it reduced water-consumption and seeds. Some groups of farmers and respondents in the research location showed their huge interest in applying the plantation system. In fact it gradually develops the land productivity. Yet, feeling unrestful to encounter difficulties become an important factor, especially how to apply the component of organic agriculture proposed. This system moreover needed a lot of organic materials. As a consequence, the land extension by the farmers was relatively limited only to belonging land and again by adopting the organic agriculture components stage by stage. In relation to its risk in the research location, there were some of the farmers who were not barely interested in this agricultural system. This then becomes a starting point of contestation between organic and non-organic agricultural practices.

In the farmer community of organic agriculture itself, in the beginning a large number of famers felt rather doubtful. They even predicted that the pattern of their organic agriculture would cause a product reduction. Farmers who early adopted the organic agricultural pattern got a negative perception from surrounding society. The doubt to maintain the agricultural productivity happened not only to the society, but also to both central and local government. However, this circumstance did not become a barrier for the community of organic agriculture to participatively implement their own creativities and experiences. This condition brought about more or less the contestation between organic and non-organic agricultural practices.

After the outstanding success of green revolution in Indonesia, especially when rice self-supporting in 1984, there 
was a systematic marginalization of local farmer's knowledge. Knowledge of non-organic agriculture had lulled the farmers to sleep, moreover the knowledge had early proved for the instant success among the farmers. The traditional knowledge of farmers, that was organic agriculture, tended to be faded out. The evidence of its success needed a long time by struggling, even strove against any institution or a sturdy structures foundation.

To answer the main problem above, so the question of the research: How is the process of contestation between organic and non-organic agricultural knowledge of agricultural practices in Bonto Lebang, Takalar?

The objective of the research is to analyze the process of contestation between the knowledge of organic and nonorganic plantation in agricultural practices in Bonto Lebang, Takalar regency.

This research is expected to produce a beneficial values for human problems, both for knowledge development and for common society.

a. For science development:

This research is generally expected to confer significant development for agronomical and sociological sectors, and particularly was expected to provide a new guidance for the elaboration of a sub-agricultural sociology, especially related to policy of environment and other structures that stand against farmer's independency as the main actor in the agricultural land maagement.

b. For public society:

Hopefully the result of this research may be a useful reference to upgrade skills and self-awareness of sociological phenomenon in the agricultural area that is needed by both individual and society so that It can prevent the trigger of conflicts among government, social organization concerned, and farmer as a direct practitioner in the agricultural products.

\section{Review of Literature}

\subsection{Contestation of Knowledge in Social Practices}

Foucault (2012) explained the connection between power and knowledge. In his book Arkeologi Pengetahuan, Foucault defines power as a strategy which is meant the power to be practiced. Power is everywhere and could not be localized. In Foucault's view, power establishes formation, rules, and inside relation, likes relative, communication media, and etc. In the eyes of Foucault, that relation is structural. Foucault wants to clarify that powers is inherent in all aspects, includes knowledge. Foucault also sees knowledge used as a power to a group of society, but bureaucracy. Power to Foucault is hidden and tricky. Power can be found in the domain of truth, discourse, outside the body, mind, and subjectivity. Fahmid (2012) clarifies that for Foucault, power are distributed in social relation and cannot be reduced into parts and economic determinant which are centralized or to its legal characters.

From the view of Foucault above, based on the present phenomenon, both organic and non-organic farming method are made use as a power for farmers.

\subsection{Organic and Non-organic Agriculture}

At first, organic agriculture is such a movement popularized in Uni Europe, as a form of resistance from agricultural development that oriented of growth or productivities, often called "Revolusi Hijau". System of organic agriculture tries to recover negative impacts of "Revolusi Hijau" (Green Revolution) by standing on fertility land as a successful key of production that pay attention to natural capabilities of land, and both plants and animals to produce a good quality for agricultural products or environment. Organic movement then develops to be an implemented philosophy in a system of agricultural holistically, so in the end emerge the term of organic agriculture as an alternative in the system of sustainable agriculture.

According to Susanto (2002), practices of organic plants intensely depends on local knowledge of farmers and condition of local farming. But, practices of organic plants commonly are easier done and measured in a circle of farmers, include : the using of organic fertilizer, the using of local variety seeds, restraining pest and plants disease, land separation, and source of water irrigation in organic and non-organic plants. Practices of organic plant is a minimal certainty that must be fulfilled by farmers if only they want to be recognized as an organic farmers. This matter caused by organic plants, which could not be seen from the using of organic plants only, but viewed from many aspects, includes farmers' attitude towards nature. In addition, land of organic plants will be truly released from chemical synthetic residue and can be stable and optimal to be produced, in case it has gone through a conversion phase from an-organic plants to be an organic one without being contaminate from synthetic chemicals during three years or more. 


\subsection{Conceptual Frame}

Foucault (2012) stated that knowledge is a power to possess other people. Relation between power and knowledge is reciprocal. It means that power and knowledge influence one another. Knowledge is in social reality.

Social reality in agricultural development was gone before knowledge of non-organic with the characteristic of hybrid fertilizer usage, controlling pest with chemicals, and usage of irrigation technique. When an-organic agriculture was found its weakness out, then emerged organic plants marked with the application of fertilizer and even organic pesticide. Those two knowledge applications took a place in Indonesia's agriculture. Moreover, those two knowledge had its own supports from multi interested parties. Government side as the policy owner, had a power to determine the application of agricultural knowledge considered more profitable. It makes agricultural practices suggested by government was counted to be legal.

But in reality, problems are more complex. When a structure or institution is the extension of government, or on the contrary, the institution is contradictive with government, therefore there two applications of knowledge appear in the field. Thus, during the agricultural development in Indonesia this day, it is underway the two applications of knowledge with its own power and dominance to influence any parties. Those two knowledge are non-organic knowledge in one side and organic agriculture in another side.

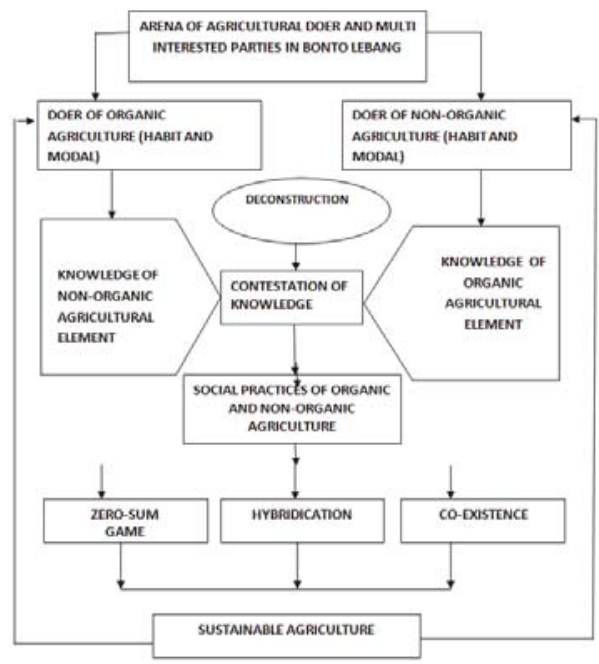

Picture 1. Conceptual Frame

\section{Research Methodology}

\subsection{Type of the Research}

The paradigm of this research is constructivism, where discourse and knowledge are seen as a social reality. Deconstruction reality in a context or social living is explorative. It means the theory born and develops in a field, emphasize on both meaning and value, and also rely on an accurate in collecting the data to reveal the real situation precisely.

This was a qualitative study, which was a study about a descriptive data both oral or even written and attitude that could be observed through agricultural doer and multi interested parties as an agent of sustainable agriculture in Bonto Lebang, Takalar regency.

This was a case study and focused on hermeneutics. The strategy of case study is a deep exploration of information. Furthermore, according to Lubis (2014), the using of strategy benefits to explain the history of science and how the construction of knowledge or scientific discourse (concept and theory) could be different in every era stated by Foucault. The researcher investigates event, activities, process or even program accurately. It aims to gain a whole and 
in-depth description from identity, in this case is a social practices of organic and an-organic agriculture. A case study provides data and then analyzed to produce a theory. The data of a case study could be obtained by interview, observation, and files. Hermeneutics is a theory or meaning-interpretation, knowledge and thought from people, and also related to the meaning of analogy of a text.

\subsection{Data and Source of Data}

The data was used in conducting this research were both primary and secondary data. Primary data was obtained by doing the interview and observation directly with farmers and multi interested parties. Type of the question is a personal facts, which is the doer gives some personal information about his/herself, attitude, and behavior as an interested organic agricultural farmers or either as an interested an-organic agricultural farmers.

While secondary data was acquired from a research institution and a research organization, such as Department of Agriculture in Takalar regency, Agricultural Elucidation Office in Bonto Lebang and some of agricultural investigators. Besides, secondary data also includes comments, interpretation, and material forms as a "second-hand information". Furthermore, data and sources of the data can be seen in the table below:

\begin{tabular}{|l|l|}
\hline Data : & Sources of the Data : \\
\hline A contestation between organic and non-organic agricultural & - Farmer of Organic plants \\
knowledge includes in many aspects, like: & - Farmer of non-organic plant \\
(1) Seeds management & - Investigator \\
(2) Land management & - Government \\
(3) Water management & - Company of agricultural media production \\
(4) Fertilizing & - Employee of SKPD \\
(5) Pest and plant-disease eradication & - People who could be discovered in the field \\
\hline
\end{tabular}

\subsection{Technique of Collecting Data}

Technique of collecting data in this research were participant observation, documentation, in-depth interview, and questionnaire admission.

Participant observation is a direct observing and listening, grasping the situation of social context, grasping the phenomenon, deciding the reality, identifying the disorder and indication of the social living of target of the research, which were organic and non-organic agricultural doer and some multi interested parties.

Documentation is a field note (the researcher as a research instrument), and in-depth interview/non structural interview. Technique of documentation is done by collecting the secondary data.

In-depth interview/non structural interview was carried out in the afternoon or evening. Number of informant was decided after observing the research location. An informant was asked about the interview material which includes daily problems, social living, social structure, social interaction of any government policy, relevance institution, and any kind of related matter with sustainable agriculture.

A questionnaire admission was done to find out the income of both organic and an-organic farmer by using a closed-questions:

\begin{tabular}{|l|l|}
\hline Data : & Technique of Collecting Data \\
\hline A contestation between organic and non-organic & Observation or involvement monitoring with farmers of \\
agricultural knowledge includes in many aspects, like : & organic and non-organic plants and also in-depth interview. \\
(1) Seeds management & \\
(2) Land management & \\
(3) Water management & \\
(4) Fertilizing & \\
(5) Pest and plant-disease eradication & \\
\hline
\end{tabular}

\subsection{Technique of Data Analysis}

The data that were collected by doing observation, in-depth interview, documentation, field-note, and non structural interview then presented to find out more information. Data analysis comprises with three parts : data reduction, data presentation, and drawing the conclusion in. Data reduction is a process of selection, interest centralization in 
simplification, abstraction, and transformation of raw data.

Technique of data analysis that were used would be explained in this table below.

\begin{tabular}{|l|l|}
\hline Data & Technique of Data Analysis \\
\hline $\begin{array}{l}\text { Contestation between the } \\
\text { knowledge of organic and non- }\end{array}$ & $\begin{array}{l}\text { Analyzing by knowledge analyze: } \\
\text { organic agriculture }\end{array}$ \\
How is the influence/cooperation/competition between the knowledge of organic and \\
non-organic agriculture consist of : contents, source, impacts, action of knowledge. \\
\hline
\end{tabular}

\subsection{Validity}

Validity of the research is a responsibility reports of the research. In this case, to validate the result of the research. In this research, the writer was using observation prolongation, rechecking, triangulation, peer-discussion, negative-case analysis, member check (Sugiyono, 2011)

\section{Result and Discussion}

\subsection{The process of contestation between knowledge of organic and non-organic agriculture}

\subsubsection{History of Organic and Non-organic Agriculture}

The society of Takalar regency has known about organic agriculture which is they commonly got from the policy maker. Just like what informant DL stated (2015), they know the knowledge of organic agriculture by its popular name "Sayuran Sehat" (Healthy Vegetables).

The knowledge of organic agriculture is non-organic agriculture, but by decreasing the amount of fertilizer and synthetic pesticide. Organic agriculture is basically fine, but slow in its growth. The process uses a bokashi. Bokashi is made based by chicken waste, husk, rice straw, a mixture of rice and bran and added EM4 fermented with a cold rice. This was similar from the statement of NDN (informant), according to him, the usage of pesticide is done if only the onset of worm comes. The disadvantage of organic agriculture is its price has not much different with the an-organic vegetables, so it is profitless in the end. In addition, organic vegetables are easily putrefy as because there is not a pesticide applied. In this village, many group of farmers put to use a non-organic vegetables. This matter is caused by the organic vegetables could not survive or easily putrefy in rainy season. Those vegetables are spinach and kale. Since the past three years, most of the farmers only have applied organic fertilizer and plant pesticide genuinely in rainy season, by putting a plastic in those vegetables. This way is to prevent plants or vegetables from the condition of too much water which can caused rotten.

Bonto Lebang village had known organic plants or vegetables since there was a helpful training from the Japanese Wakiko Ito in 2010. It was a realistic corporation with JICA (Japan International Corporation Agency). Basic idea from JICA was to product a high quality plants or vegetables. Because of that, Indonesia joined JICA in Japan in 1999. Also Wardah (2012), stated that farmer responses towards the using of organic fertilizer to rice plants was in average category, wether it is in cognitive, affective or even psychomotoric aspect as well.

There were some kind of training program like how to make a plant pesticide and organic fertilizer, while on the other hand, training stuff were prepared by local farmers. The first way to make a plants pesticide is collect all kind of leaves in Bonto Lebang, such as kale leaf, spinach leaf, cabbage leaf, etc. After it is collected, those leaves then put into a big drum with a very closed lid. If it is already filled about three quarters of drum, then watered about a quarter left. Later, close the lid closely. After a week, those green leaves will turn into brown and smelled. This bad smell then causes pest likes worm does not like plants sprayed with that plants pesticide.

On the other hand, the making of organic manure is like : mix dung (can be chicken or cow), husk, and a mixture of rice and bran with ratio $=1: 0,5: 0,5$. Then mixed it evenly. For its faster fermentation, add EM4 at the rate of two shot glasses. EM4 is about Rp. 15.000,-litre. Next, add one shot glass unfinished black sugar made by local factory, Pabrik Gula Takalar (Takalar Sugar Factory). That unfinished black sugar is fused with two litres of water then mixed together and hushed about three days. If it is done, this organic manure then put into sack with the capacity $50 \mathrm{~kg}$ and can be immediately used. 


\subsubsection{Power and Knowledge in Organic and Non-Organic Agriculture}

Basically, the main goal of agricultural sector is to increase the production as maximum as it can be, so in the end, food self-sufficiency will be reached. Especially for non-organic agriculture, the program is run by the directive counseling.

Government through Non Governmental Organization and others institution has some kind of tendency to control farmers with a 'kind' way. It is to control knowledge, discourse, and make a good definitions about anything that considered to be good ways. This new conquest model makes people as the knowledge objects and discourse objects. The main founder is a knowledge of modern people (Ritzer, 2004). To Foucault (1972) in Ritzer (2004), knowledge is the power to gain people.

The refusal to any kind of governments' policy shows some truth indication of Foucault, so that kind of condition named as a misorder capitalism, where the emergence of capital classes dominantly. Its dominant is not only in a state, but also control to civil society through out a consumerism cultures. As Foucault (2012) stated, history in each era had a vision, description, classification, and understandings of specific world. Ways of thinking was not determined by people, but decided by a dominant discursive structural in that time. Discursive structural could be a written text, oral verbal and non verbal languages, institution practices, and many more. These types of discursive structural had belongs to a dominant media party to exploit some interest both organic and an-organic farmers.

Foucault put down dominance as not commonly had by state, moreover some groups possessed a sort of particular power. By discourse, they controlled views, belief, and action by each individual. This discourse became a keyword that discussed and offered by Foucault as the rationale of his thought that used by any dominances to win over others in achieving goals. Based on his views, society turned into subjects created by unaware systems and dominance network at all. Here, some kind of roles from Non Governmental Organization, Certified Institution, and many more have its own powers. Non Governmental Organization and Certified Institution create systems unwittingly by farmers.

From the illustration above, it can be inferred that organic farming ways, the developing knowledge about organic agriculture and also dominances from any sides, such as government, has a close relation as a set of regulation systems.

According to Foucault (2012), Long (2001), and Salman (2012), in a condition of applied knowledge (knowledge about organic and non-organic agriculture) of a social reality, there must be a 'knowledge interface', or commonly known as a knowledge contestation. Thus, knowledge contestation that is on going in organic agriculture development, in any kind of aspects, like seeds and manure-providing and land-managing, engaged respons from every local sub-systems such as household, government, local communities, and marketing varied based on their needs.

Else, Foucault also stated that discourse creates and constructs a particular event and a composite from its units of event then form a known narration. One community usually has many sort of discourses that differ each other, but when dominance chooses and supports a particular discourse, it is made that particular discourse becomes well-known and dominant, quite contrary for other discourses that will be marginalized and submerged.

Foucault also added that society becomes a created subjects by the systems and power network that is commonly unaware by the subject. Power or dominance creates knowledge, knowledge and power interplay directly one another. In more specific term, Foucault declared that power or dominance and knowledge impact one another directly. There will be no power without the help of knowledge, vice versa, each form of knowledge is a sign of power tendency.

Furthermore, to Foucault (1972), the basis of capitalism tends to control state smoothly. It is done by controlling the knowledge, discourse, and makes a good definition of anything that considered to be good ways. This new conquest model makes people as the knowledge objects and discourse objects. The main founder is a knowledge of modern people (Ritzer and Goodman, 2004).

Suharsaputra (2004) said that knowledge development, technology in particular, or known as technological development, as a application of knowledge that has a rapid changes. Those changes impacts the view of society about the essence of knowledge, the process, and the significances to society, hence knowledge tends to be considered as the only truth as a basis in life and an important basic influences human's behavior.

There must be habit and old practices that valid and give some profit, like : the usage of pesticide is one of old habit. The result of pesticide is immediately seen. Farmers in Bonto Lebang village focuses in profitable aspects in a short time, but they ignore long-term significances.

The developing model of agricultural knowledge in Indonesia are dominated by scientific works of agricultural scientists. Almost various result and technology tends to refer to the latest agricultural knowledge and modern technology that has been expanded in developed countries. The result of the research then tried to be adapted to farmers, projects, government program or even private ways in a form of agricultural media technology products, that can be gained by farmers by "buying".

Furthermore, Ardhian (2009) stated that agricultural knowledge development through knowledge and technology 
transfer (more modern ways) to farmers (considered to be traditional ways) and still on going process. Farmers are viewed as a 'receiver' of knowledge through a passive adaptation towards knowledge and technology that produced by scientists from Research Institution.

During the knowledge development and modern agricultural technology, there such a developmental model that uses two different ways, they are a continue agricultural systems that respects locality aspects, include opening some opportunite for farmers participation in evolving agricultural knowledge. The on going main principal of agricultural are stressed of a clean environment, social justice, economic worth based on local format measurement and appreciation upon a living things in a agricultural world. It gives a space for the expanding a local agricultural knowledge. Farmers are deemed to be a passive adaptor yet as a subject in developing of agricultural knowledge.

In a context of continued agriculture, knowledge of farmers is a prominent wick instead. Local knowledge in a term of agriculture is not a prior knowledge that lead up to before practices. However, the knowledge arises and develops along with the direct experiences of practice. Knowledge is actually a product of perception, a learning process and rationality of farmers by virtue of daily experiences. Technology that is offered equal with the knowledge of farmers is an appropriate technology, needs required, cheap, and can be easily applied to farmers cultivation works. The regeneration process could be hereditary or sharing with others farmers.

Local knowledge is a result of learning process based on farmers' perception as the main doer to organize local resources. Knowledge dynamization as an influential process of the pattern of mineral resources especially in the local agricultural system. Sometimes, the practice of local agricultural system can hand over a potential ideas for using and managing those available resources eternally (Sunaryo and Joshi, 2003). Thus, local disinterment effort is needed to increase mineral resources in a matter of utilization, management, and development.

In making a decision, some of farmers need times to explore all kind of possibilities and integrate it with other studies from another sources accurately, apart from innovative adaptation accurately and innovative adaptation from outside, a lot of reports show that farmers oftentimes innovatively to do a small experiment about new ideas routinely and observe it through.

As a matter of fact, farmer has a heap of experiences procured by monitoring, observing, and doing farming activities since a long time from previous generations. As a result, those activities then made them learn to prevent surroundings problems, as known as "ecology wisdom" or even "local wisdom" (Soemarwato, 1982). Beneath it all, local wisdom could be made the best use as a source of inspirations to create a new innovation of technology in helping forward agricultural development for the nation.

Supporting the ideas above, modern knowledge needs to be equal to local wisdom as because local knowledge and abilities of society in main use of rural resources is not enough against outside interference (Rositah, 2005). Hence, best efforts for that is doing the contestation between local and modern knowledge in agricultural development dynamics. Each could not prevail others bussines off nor such be passive only to accept the condition of mineral resources that tends to get a degradation.

To give a context from any contestation interest in agricultural development, it seems that a visible image of its relevance between local knowledge and modern knowledge in agricultural sector with any other context is needed. It begins from the history, production, figuration, distribution, and utilization that makes ways of thinking and action. Each action by each individu basically products new knowledge to another doer (de Certeau, 1984 and Foucault, 1980). Furthermore, this things continue happening until it constructs social structures like norms, convention, rules, and principles, but then it does not last forever. It needs to be renewed and transformed along with developing knowledge.

Contestation takes place in dissident or controversial situation. Each issues has three things, such as potential side, contestation side, and acceptance side.

\section{Conclusion}

The result of this research shows that the contestation between organic and non-organic agricultural knowledge, whether in the aspects of seeds-providing, fertilizing, and land-managing, involve any kind of respons from each local of subsystems, they are household, government, local communities, and marketing. For the people of Bonto Lebang village Takalar regency in particular, knowledge of organic agriculture is Non-organic agricultural knowledge that has been through a deconstructive as the consequences of field works and also from the outside information or counseling that reconstruct from its practices. Meanwhile, some part that go into the main changes is the fundamental one, which are cultivation (plants pesticide) and fertilization (organic fertilizer). 


\section{References}

Arikunto, Suharsimi. (2013). Prosedur Penelitian Suatu Pendekatan Praktik. Jakarta: Penerbit Rineka Cipta.

Bourdieu, Pierre. (2010). Arena Produksi Kultural (Translated by Yudi Santosa). Bantul: Kreasi Wacana.

Fahmid, Imam Mujahidin. (2004). Gagalnya Politik Pangan di bawah Rezim Orde Baru: Kajian Ekonomi Politik Pangan di Indonesia. Jakarta: Sandi Kota.

Fahmid, Imam Mujahidin. (2012). Identitas Dalam Kekuasaan. Makassar: Penerbit Ininnawa.

Fakih, Mansour. (2001). Sesat Pikir Teori Pembangunan dan Globalisasi. Yogyakarta: Insist Press.

Foucault, Michel. (2012). Arkeologi Pengetahuan. IRCiSoD, Yogyakarta.

Jenkins, Richard. (2013). Membaca Pikiran Bourdieu. Yogyakarta: Kreasi Wacana.

Laoubi, Khaled. 2009. A Typology of Irrigated Farms as a Tool for Sustainable, Agricultural Development in Irrigation Schemes. International Journal of Social Economics, 36(8), pp. 813 - 831.

Mardiyaningsih, Dharmawan., and Tonny. (2010). Dinamika Sistem Penghidupan Masyarakat Tani Tradisional dan Modern di Jawa Barat. Jurnal Transdisiplin Sosiologi, Komunikasi dan Ekologi Manusia, April, pp. 98 - 127.

Munthe, Hadriana Marhaeni. (2007). Modernisasi dan Perubahan Sosial Masyarakat dalam Pembangunan Pertanian: Suatu Tinjauan Sosiologis). Jurnal Harmoni Sosial, September 2007, II (1).

Ritzer, George., and Goodman, Douglas J. (2010). Teori Sosiologi: Dari Teori Sosiologi Klasik sampai Perkembangan Mutakhir Teori Sosiologi PostModern. Yogyakarta: Kreasi Wacana.

Salman, Darmawan. (1995). Arah Perubahan Sosial di Pedesaan Pasca Revolusi Hijau. Analisis CSIS.

Salman, Darmawan. (2012). Sosiologi Desa Revolusi Senyap dan Tarian Kompleksitas. Makassar: Penerbit Ininnawa.

Samun, Suryani., Didi Rukmana., and Syam, Sylvia. (2011). Partisipasi Petani dalam Penerapan Teknologi Pertanian Organik pada Tanaman Stroberi di Kabupaten Bantaeng. Jurnal Analisis Kebijakan Pertanian 4(2), pp. 1 - 12.

Scott, James.C. (1993). Perlawanan Kaum Tani. Jakarta: Yayasan Obor Indonesia.

Siregar, Chairil N. (2006). Analisis Sosiologi terhadap Inovasi Teknologi. Jurnal Sosioteknologi. 9th Ed of 5, December, pp. 25 - 37.

Sugiyono. (2011). Metode Penelitian Kuantitatif, Kualitatif dan R\&D. Bandung: Penerbit Alfabeta.

Sutanto, Rachman. (2002). Penerapan Pertanian Organik, Pemasyarakatan dan Pengembangannya. Yogyakarta: Kanisius.

Syamsudin, Tati Suryati., and Aktaviyani, Sri. (2009). Penerapan Pemupukan Pada Pertanian Padi Organik dengan Metode System of Rice Intensification (SRI) di desa Sukakarsa kabupaten Tasikmalaya. Jurnal Agroland 16 (1), pp.1-8.

Thangchungmunga. (2009). Agrarian Change and Social Transformation among the Mizo (The Tribal State in North-East India). International Journal of Social Economics, 36(8), pp. 261 - 276.

Turner, Bryan S. (2012). Teori Sosial dari Klasik sampai Post Modern. Yogyakarta: Pustaka Pelajar.

Vancil, David L. (1993). Rhetoric and Argumentation. Boston: Allyn and Bacon.

Wardah, Siti. (2012). Respon Petani terhadap Penyuluhan Penggunaan Pupuk Organik pada Tanaman Padi. [Unpublished Dissertation]. Makassar.

Widiarta, Aero., Adiwibowo, Soeryo., and Widodo. (2011). Analisis Keberlanjutan Praktek Pertanian Organik. Jurnal Transdisiplin Sosiologi, Komunikasi dan Ekologi Manusia, April 2011. 